DOI 10.15393/j10.art.2016.2862

Юлия Александровна Дунаева

младший научный сотрудник ФГБУН «Библиотека Российской академии наук» (Санкт-Петербург, Российская Федерация) djdiuna@rambler.ru

\title{
ЕЩЕ ОДНА ВЕРСИЯ АДРЕСА «ДОМА СТАРУХИ-ПРОЦЕНТЩИЦЫ»
}

Аннотация. Автор статьи обращает внимание на несоответствие общепринятой версии адреса «дома старухи-процентщицы» (наб. канала Грибоедова, 104) тексту романа «Преступление и Наказание». Ссылаясь на более ранние работы других исследователей и собственные наблюдения, автор доказывает, что «дом старухи-процентщицы» следует искать на правом берегу канала Грибоедова к западу от Столярного переулка. Автор предлагает новую возможную версию адреса «дома старухи-процентщицы»: Казанская, 60 / Фонарный, 18 / наб. кан. Грибоедова, 83.

Ключевые слова: топография романа «Преступление и Наказание», «дом старухипроцентщицы»

$\mathrm{B}$ настоящее время общепризнанным местом расположения «дома старухи-процентщицы» считается здание, современный адрес которого: наб. канала Грибоедова, 104 / проспект Римского-Корсакова, 25 / Средняя Подьяческая, 15 (см.: [3, 340]; [13, 54]; илл. 1, цифра 1). Эта версия появилась в литературе, касающейся топографии «Преступления и Наказания», в конце 50-х годов XX века $[14,425]$, была использована в экскурсии «Петербург Достоевского», разработанной А. Ф. Достоевским и С. В. Беловым $[3,326]$, и получила распространение в публикациях 70-х годов $[4,50]$; $[6,3] ;[7,182]$; $[9,7] ;[11,183]$. В современной литературе, рассчитанной на массового читателя, данная версия обычно подается как единственно существующая $[5,182]$; $[10,244-246]$. Такая же позиция встречается и у современных западных исследователей [15, 53-54].

Однако в некоторых более ранних публикациях этот адрес рассматривался лишь как один из возможных $[4,50] ;[6,3] ;[7,184]$, или даже заведомо неверный [2, 191-192]. Исследователи обращали внимание на то, что положение дома № 104 по набережной канала Грибоедова не соответствует некоторым топографическим описаниям в тексте романа. Прежде всего, отмечали $[2,191] ;[7,185-186]$, что детально описанный в седьмой главе первой части путь Раскольникова после убийства ${ }^{1}$ не может выстроиться при движении от ворот этого дома, так как, по тексту романа, герой, покинув двор, поворачивает налево по улице, доходит до некоего переулка, поворачивает в него и по переулку выходит на канал. В ближайших окрестностях дома № 104 по каналу Грибоедова вообще нет никакого переулка. Если бы герой оказался на Средней Подьяческой улице, то непосредственно по ней он вышел бы на набережную канала, причем двигаясь в любую сторону. 
Схема расположения улиц в той части Санкт-Петербурга, где происходит основное дейстие романа «Преступление и наказание».

Городские топонимы соответствуют времени действия романа.

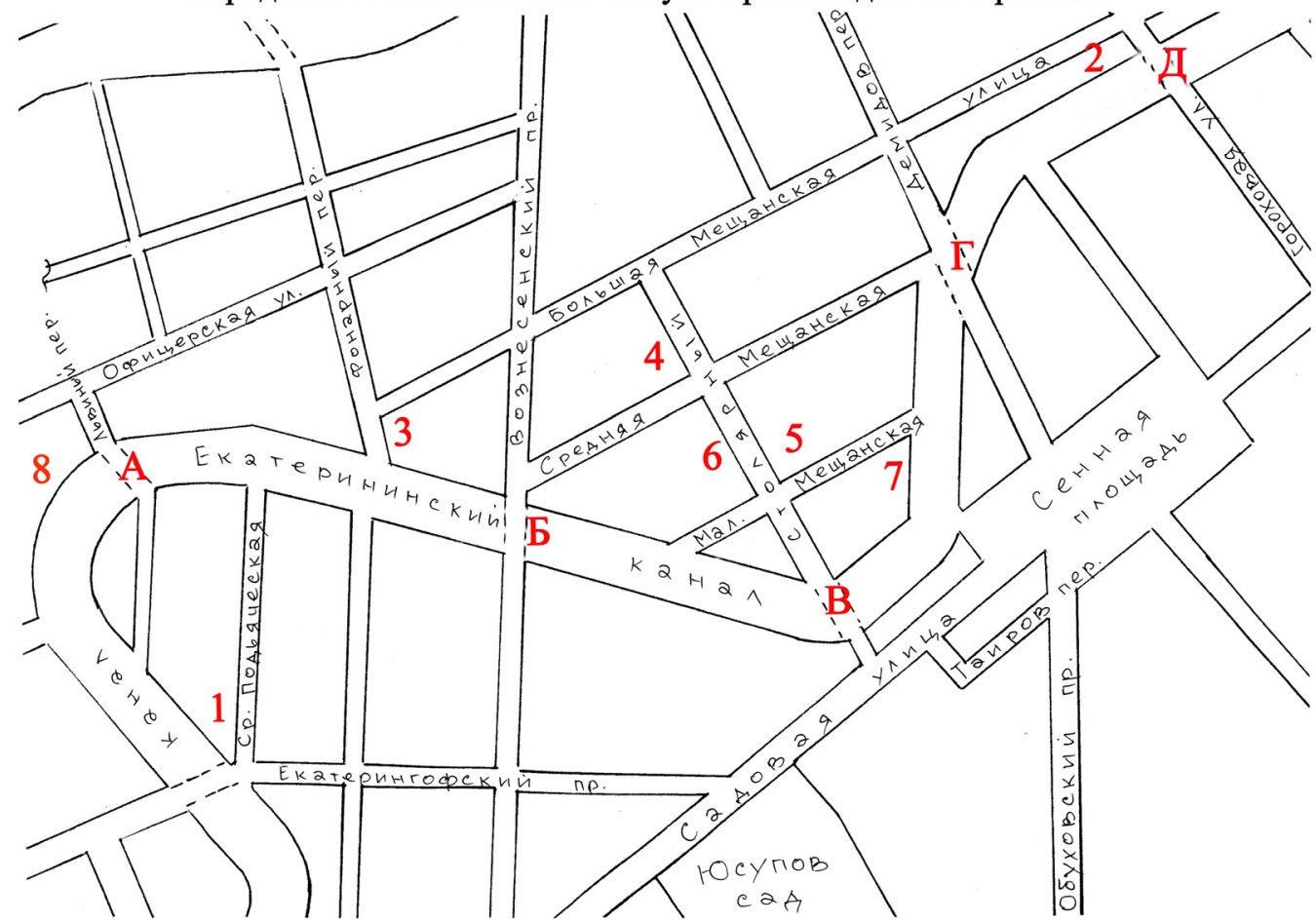

Илл. 1

Еще одна проблема, связанная с данной версией адреса «дома старухипроцентщицы», заключается в том, что, в соответствии с административным делением Санкт-Петербурга, действовавшим в июле 1865 года², «дом» находился на территории Спасской полицейской части ${ }^{3}$, а убийство старухи произошло в той же полицейской части, в которой жил Раскольников, то есть - в Казанской ${ }^{4}$. Содержащиеся в тексте романа указания на то, что преступление было совершено Раскольниковым на территории той же полицейской части, в которой он проживал, отмечал еще Б. В. Федоренко [2, 191-192]. Помимо приведенных им цитат, можно обратить внимание и на то, что после несчастного случая с Мармеладовым и его смерти к нему на квартиру приходит, в соответствии со служебными обязанностями, Никодим Фомич, пристав той же участковой полицейской конторы, к которой приписан и Раскольников (145). Это значит, что семейство Мармеладова проживало в том же полицейском участке, что и Раскольников. Но в тексте романа есть указания и на то, что убийство старухи-процентщицы произошло где-то совсем рядом с домом Козеля, в котором проживал Мармеладов. Например, остановившийся в том же доме Лужин сообщает, что слышал 
о данном происшествии, так как проживает «в соседстве» (117). Вряд ли он сказал бы так, если бы убийство произошло на другой стороне канала. Значит, Раскольников и Алена Ивановна жили, если и не на территории одного полицейского участка, то в одной полицейской части. Кроме того, Порфирий Петрович служил приставом следственных дел в той же полицейской части, где жил главный герой. Это мы узнаем от Разумихина, который сначала сообщает, что переехал в ту же часть, где живет Раскольников (98), а затем говорит, что Порфирий Петрович - «здешний пристав следственных дел» (104). Таким образом, «дом старухи-процентщицы» следует искать не на левом, а на правом берегу канала Грибоедова. Учитывая, что от ворот дома Раскольникова до ворот дома старухи-процентщицы должно быть всего 730 шагов (7), дом должен находиться недалеко от Столярного переулка.

Одна версия адреса «дома старухи-процентщицы», которая удовлетворяет этим требованиям, была предложена Б. В. Федоренко [2, 203]; [6, 3]. Точной нумерации дома он не сообщил, но считал, что «дом» находился поблизости от Гороховой улицы, между Большой Мещанской (совр. Казанской $)^{5}$ и «канавой» - каналом Грибоедова (Илл. 1, цифра 2). Если предположить, что Раскольников после убийства вышел на Большую Мещанскую улицу и повернул налево, то роль нужного по тексту романа переулка мог бы сыграть Демидов переулок (Гривцова). Расстояние от данного дома до Столярного переулка может соответствовать 730 шагам [2, 203]. Таким образом, данная версия адреса «дома старухи-процентщицы» больше соответствует тексту романа, чем дом № 104 по каналу Грибоедова. Однако есть некоторые проблемы, которые не позволяют считать ее верной.

Если мы посмотрим на схему расположения улиц в данной части города (Илл. 1), то увидим, что наиболее удобный путь от любого из домов, которые рассматриваются в качестве «дома Раскольникова» (см.: [13, 47-48]; илл. 1, цифры 4, 5 и 6), до «дома старухи-процентщицы», предложенного Б. В. Федоренко, пролегал бы по Столярному переулку и Большой Мещанской улице. Отправившись на «пробу», Раскольников не должен был бы поворачивать в сторону Кокушкина моста (Илл. 1, литера В), выйдя из ворот своего дома (5). Второе несоответствие заключается в том, что, по дороге к месту убийства, Раскольников не должен был бы проходить мимо Юсупова сада (60), так как для этого ему пришлось бы не просто сделать крюк по пути, а повернуть в сторону, прямо противоположную той, в которую ему надо было двигаться (Илл. 1$)^{6}$. Учитывая, что герой спешил, это кажется маловероятным. В романе задача героя сформулирована так: «...он увидел, что <...> уже десять минут восьмого. Надо было и торопиться, и в то же время сделать крюк: подойти к дому в обход, с другой стороны...» (60). Наиболее логичный и при этом не сильно удлиняющий время пути обходной маршрут от Столярного переулка до места расположения «дома старухипроцентщицы», по версии Б. В. Федоренко (Илл. 1, цифра 2), мог пролегать 
от Кокушкина моста по Садовой улице через Сенную площадь до Гороховой, затем налево до Каменного моста (Илл. 1, литера Д), на правый берег канала, к домам, выходящим на набережную и Большую Мещанскую. В этом случае герой подошел бы к месту преступления, действительно, с другой стороны - по Гороховой улице, а не по набережной канала или Большой Мещанской, как если бы он шел, двигаясь более коротким путем (Илл. 1). Поворот в сторону Юсупова сада при такой задаче героя объяснить трудно. В этом случае ему пришлось бы, пройдя мимо сада, повернуть на Екатерингофский проспект, затем на Вознесенский и либо идти к дому старухи по набережной канала, либо выходить на Большую Мещанскую улицу, что, с одной стороны, как минимум в два раза удлинило бы путь, а, с другой стороны, не создало бы впечатления подхода к месту преступления с несвойственной герою стороны. Получается, что заданный в романе проход мимо Юсупова сада по пути к месту преступления заставляет искать «дом старухи-процентщицы» не к востоку, а к западу от Столярного переулка.

Возможна еще одна версия расположения «дома старухи-процентщицы», не отмеченная ранее исследователями. Это дом, современный адрес которого: Казанская ул., 60 / Фонарный пер., 18 / набережная канала Грибоедова, 83 (Илл. 1, цифра 3). Сейчас на этом месте находится построенный в 1911-1912 гг. по проекту архитектора К. Н. де Рошефора доходный дом В. П. Лихачева ${ }^{7}$ Судя по архивным документам, в интересующее нас время, то есть в середине 60-х годов XIX века, этот участок земли и все постройки на нем принадлежали жене статского советника Софии Кузьминичне Пащенко ${ }^{8}$. Ее фамилия указана и в справочном издании того времени․

В Центральном государственном историческом архиве Санкт-Петербурга хранятся планы двора и чертежи зданий, на основании которых можно представить, насколько дом Пащенко соответствовал дому, описанному в романе ${ }^{10}$. Однако прежде чем перейти к рассмотрению архивных документов, нужно пояснить, почему данное расположение дома кажется заслуживающим внимания.

Как следует из современного адреса этого дома (Казанская, 60 / Фонарный, 18 / наб. кан. Грибоедова, 83), здание выходит сразу на две улицы и набережную канала. Таким образом соблюдается первое из заданных в романе условий: «С замиранием сердца и нервною дрожью подошел он к преогромнейшему дому, выходившему одною стеной на канаву, а другою в -ю улицу» (7). В данном случае роль улицы, название которой в винительном падеже заканчивается на букву «ю», играет Большая Мещанская (Казанская). Возможно, именно потому, что название улицы состояло из двух слов, Федор Михайлович и оставил от него всего одну букву, в отличие от зашифрованных вариантов Столярного переулка и Кокушкина моста, в которых оставлены первая и последняя. 
Теперь вернемся к вопросу, касающемуся переулка, в который должен был свернуть Раскольников, чтобы выйти на канал. Его роль в данном случае может играть Фонарный. Таким образом, выполняется еще одно заданное в романе условие.

Расстояние от дома № 60 по Казанской улице до домов в Столярном переулке может соответствовать 730 шагам, о чем мы подробнее скажем ниже, когда рассмотрим расположение построек на архивных чертежах.

Полное название дела, касающегося данного участка земли, в фондах ЦГИА СПб звучит так: «Чертежи дома на участке, принадлежавшем Шипулинскому, С. Пащенко, В. М. Юсему, наследникам Юсема, В. П. Лихачеву по Казанской ул., 60, Фонарному пер., 18 и наб. Екатерининского кан., 83. 1833-1915» ${ }^{11}$. Сопоставляя чертежи построек разного времени, можно видеть, что площадь данного участка земли в указанные годы не менялась. Во время владения им С. К. Пащенко она была такая же, как и во время владения В. П. Лихачева. Сохранившееся здание постройки 1911-1912 гг., шестиэтажный дом В. П. Лихачева, действительно, производит впечатление «преогромнейшего». Однако сказать что-либо относительно построек, занимавших данную площадь земли в середине 60-х годов XIX века, можно только на основе архивных чертежей.

Наиболее близки к интересующему нас времени документы, датированные 1859 годом. Их производство было связано с рассмотрением прошения владелицы участка Софии Кузьминичны Пащенко о надстройке 4-го этажа на существующем трехэтажном доме. Общее присутствие правления Первого округа путей сообщения, состоявшееся 8 июня 1859 года, постановило надстройку дозволить ${ }^{12}$. В связи с этим был составлен «План двора жены статского советника Софии Пащенко 2-й Адмиралтейской части 3-го квартала под № 19» ${ }^{13}$. Именно на основании этого плана мы можем судить о том, насколько данный двор и его постройки соответствуют описанным в романе (Илл. 2).

На плане хорошо видно, что участок С. К. Пащенко был занят тремя постройками, две из которых смыкались друг с другом. Двор сложной конфигурации имел два выезда: на Фонарный переулок и на Большую Мещанскую улицу. «Входящие и выходящие так и шмыгали под обоими воротами и на обоих дворах дома», - говорится в романе (7). На данном чертеже мы видим, что ворот у двора, действительно, было двое, но двор был один. Однако из-за его сложной конфигурации и из-за того, что второй выезд не был виден со стороны Фонарного переулка, можно было подумать, что дворов два. После убийства Раскольников мог воспользоваться выходом на Большую Мещанскую, повернуть налево по улице, дойти до переулка, повернуть в него и выйти на набережную Екатерининского канала (Илл. 2). 
План двора Софии Кузьминичны Пащенко. 1859 год. ЦГИА СПб. Ф. 513. Оп. 102. Д. 3321. Л. 22 об.

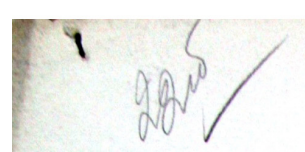

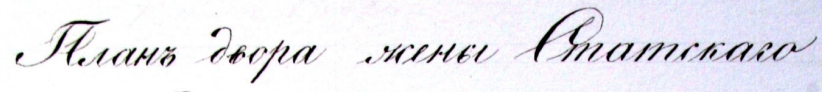

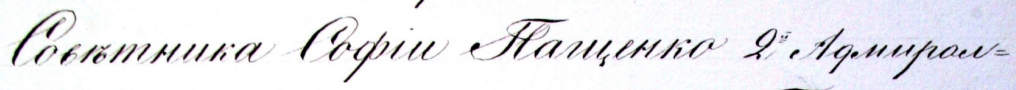
maicnoii rarme 3 libafincuea node. $\sqrt{=19}=$

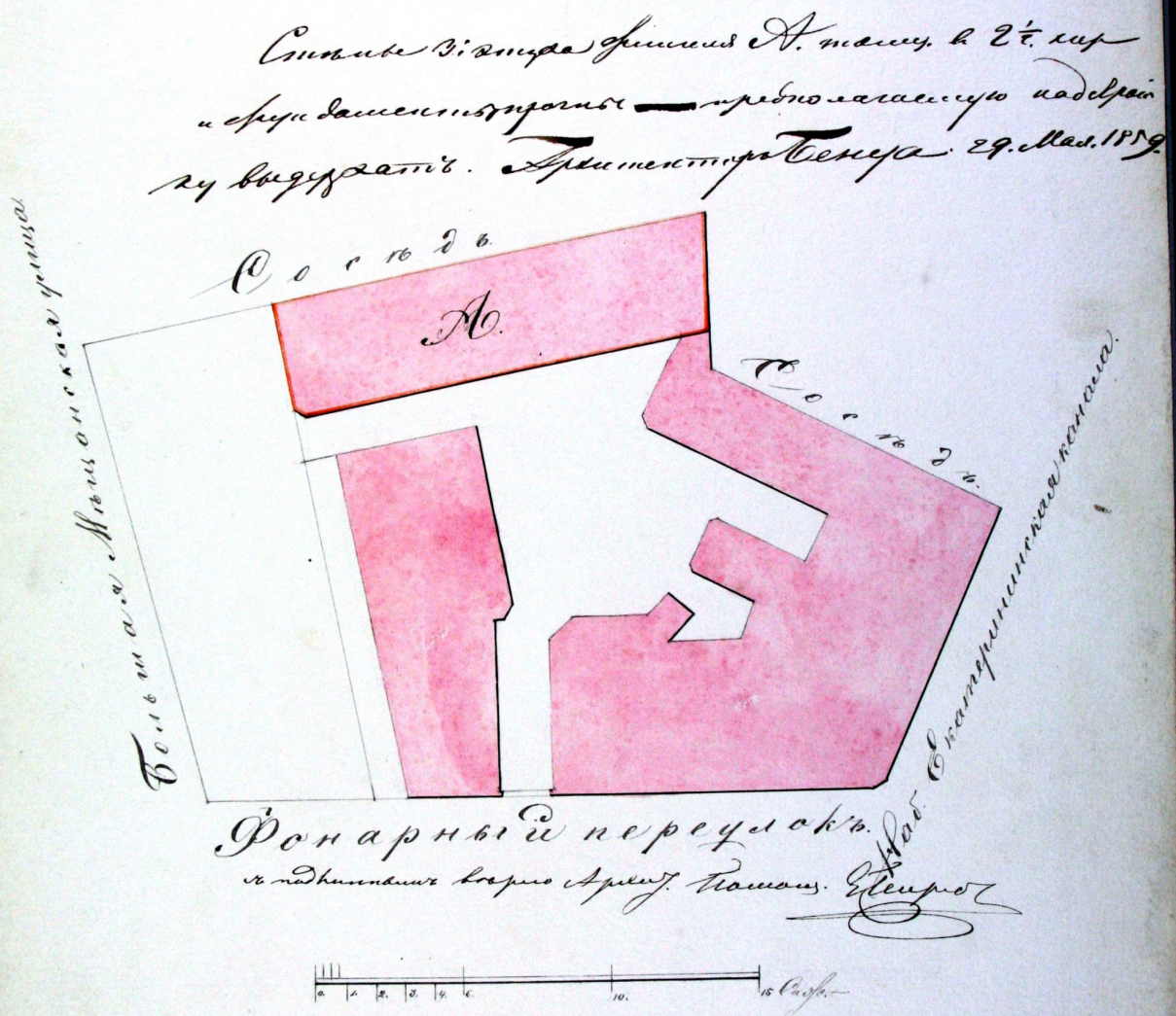

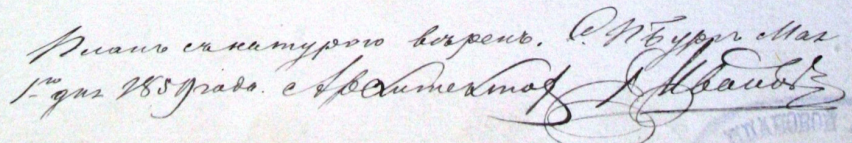

Илл. 2 
В какой именно из частей дома могла жить старуха-процентщица? Мы знаем, что квартира, в которой жили Алена Ивановна и Елизавета, находилась на четвертом этаже $(7,61)$. Из всех построек С. К. Пащенко четырехэтажной могла быть только одна. На плане она обозначена литерой «А» (Илл. 2). Именно на ней по полученному в 1859 году дозволению должен был быть надстроен четвертый этаж ${ }^{14}$. Самое большое по площади здание сложной конфигурации было трехэтажным ${ }^{15}$. Неправильный прямоугольник слева от него - это двухэтажная хозяйственная постройка ${ }^{16}$ (Илл. 2). Таким образом, старуха-процентщица могла проживать только в здании, обозначенном литерой «А». В том же архивном деле сохранился проектный чертеж, показывающий, как будет выглядеть здание после надстройки четвертого этажа ${ }^{17}$ (Илл. 3).

\section{Проектный чертеж четырехэтажного дома на участке}

Софии Кузьминичны Пащенко. 1859 год.

ЦГИА СПб. Ф. 513. Оп. 102. Д. 3321. ЛЛ. 23-24

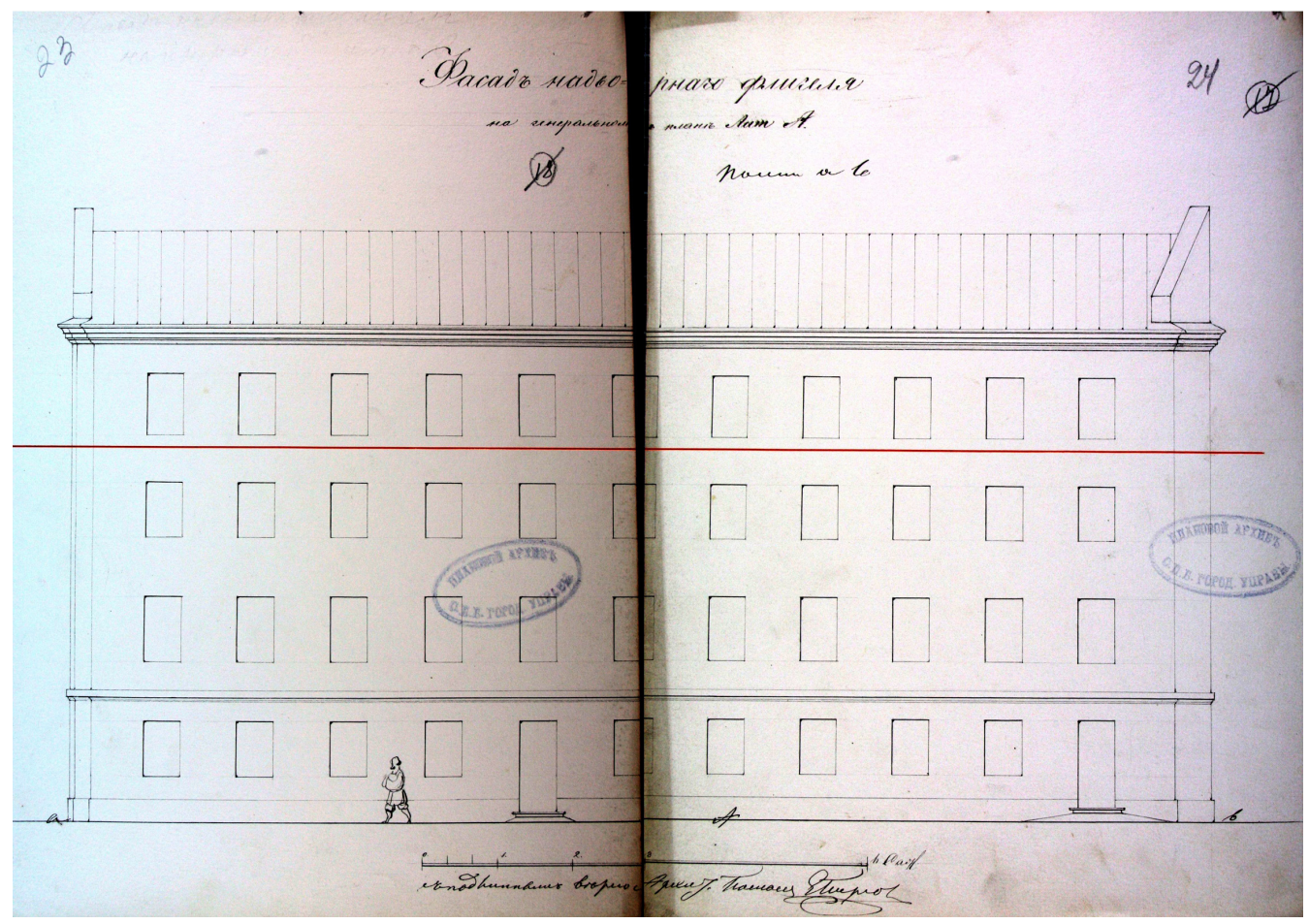

Илл. 3

Рассмотрев план двора, мы сталкиваемся с одним несоответствием тексту романа. Чтобы попасть на лестницу, ведущую к квартире старухи, Раскольников, войдя во двор, должен был сразу повернуть направо $(7,60)$. 
По плану участка С. К. Пащенко получается, что он должен был повернуть налево. Объяснить данное несоответствие можно лишь допустив, что Достоевский нарочно изменил направление движения на противоположное, чтобы избежать излишней узнаваемости дома после публикации романа. Можно привести здесь и соображение Д. С. Лихачева, которое он высказывает, полемизируя с К. А. Кумпан и А. М. Конечным, ссылаясь на их известную статью [7]: «Если Достоевский и ошибался, называя в одном случае этаж, на котором жила Соня Мармеладова, третьим, а в другом случае вторым, то это нисколько не свидетельствует о том, что он сознательно стремился деконкретизировать события, описать их топографически неточно. Неточности были неизбежны именно в силу стремления к точности, в силу того, что автору невозможно было запомнить и повторить все те точные, в смысле количества шагов, поворотов и переходов, указания, которые он столь часто делал в своих романах» $[8,54]$.

Можно ли было употребить эпитет «преогромнейший» в отношении дома С. К. Пащенко, учитывая, что самая высокая постройка на ее дворе была четырехэтажной, а самая большая по площади - трехэтажной? Возможно, в данном случае, Достоевский имел в виду большое пространство, которое занимали все постройки участка, выходившего сразу на три улицы.

Среди четко указанных в романе признаков «дома старухи-процентщицы» есть еще такой, как сторона света, на которую выходили окна старухиной квартиры. Это должен быть либо запад, либо юго-запад, так как летнее заходящее солнце ярко освещало комнату (8). В случае с четырехэтажной частью дома С. К. Пащенко данное условие как раз выполняется точно. Ее фасадная стена ориентирована параллельно Фонарному переулку и смотрит на запад-юго-запад. Постройки, расположенные перед ней, не могли заслонять окна четвертого этажа от лучей заходящего солнца, так как были более низкими ${ }^{18}$.

Автор данной статьи проводила самостоятельные подсчеты шагов между расположенными в Столярном переулке разными «домами Раскольникова» и Казанской, 60. Наиболее близкое к указанному в романе число шагов получалось при движении от ворот дома № 9 по Столярному переулку ${ }^{19}$. Маршрут движения был следующий: Столярный, 9 - Казначейская улица - набережная канала Грибоедова - Фонарный переулок - Казанская улица (Илл. 1). При прохождении этого маршрута человеком среднего роста (170 см) неторопливым прогулочным шагом от ворот дома № 9 по Столярному переулку до предполагаемого входа во двор дома С. К. Пащенко со стороны Казанской улицы получалось 720-735 шагов.

В тексте романа есть еще два косвенных указания на топографическое расположение «дома старухи-процентщицы».

В первой главе второй части, направляясь в свою квартальную полицейскую контору, Раскольников доходит до поворота во «вчерашнюю» улицу и смотрит «на тот дом» (74). В июле 1865 года дома по Столярному переулку 
относились к 3-му кварталу Казанской полицейской части, контора которого находилась по адресу: набережная Екатерининского канала, 67 (Илл. 1, цифра 7$)^{20}$. Если бы Раскольников направился в контору от своего дома сразу, то он не смог бы заглянуть в Большую Мещанскую улицу по пути, так как ему нужно было бы двигаться в противоположном направлении. Остается предположить, что он нарочно сначала дошел до угла Столярного и Большой Мещанской, чтобы взглянуть «на тот дом», и потом направился в контору. Точно такое же предположение приходится сделать, если допустить правильность адреса «дома старухи-процентщицы», предлагаемого Б. В. Федоренко (см.: [2, 203]; [6, 3]; илл. 1, цифра 2). От любого из «домов Раскольникова» до угла Казанской и Столярного совсем недалеко, не более двух кварталов. Но чтобы заглянуть в Среднюю Подьяческую улицу и увидеть «дом старухипроцентщицы», находящийся по адресу: наб. кан. Грибоедова, 104, - Раскольникову пришлось бы проделать длинный путь в противоположном от конторы направлении, что представляется маловероятным. Героем в этот момент владеет желание как можно скорее разрешить мучительное неведение относительно причины, по которой его вызвали в контору, им овладевает даже «цинизм гибели», он готов к худшему для него повороту событий, но не может терпеть неизвестность. «Господи, поскорей бы уж! <...> Только бы поскорей!..», - так думает Раскольников, направляясь в контору (74). Кроме того, в комнате «в обойной дыре» остались все награбленные вещи, хранить которые там опасно. «...А тут, пожалуй, нарочно без него обыск», - такое опасение тоже приходит в голову Раскольникову (74). Учитывая состояние героя, трудно предположить, что он, вместо того, чтобы идти в контору, до которой всего «с четверть версты» (74), отправится в этот момент совсем в другую сторону, на Екатерингофский проспект, или пойдет по противоположному берегу канала, чтобы взглянуть на дом, находящийся на Средней Подьяческой улице (Илл. 1). Таким образом, оба адреса «дома старухи-процентщицы» с расположением на Большой Мещанской (Казанской) меньше противоречат тексту романа, чем при расположении: Грибоедова, 104 / Средняя Подьяческая, 15.

В шестой главе второй части романа Раскольников оказывается у дома старухи, двигаясь от -ского моста (131). В литературе существуют две версии относительно того, что это за мост. Одни авторы полагают, что это - Вознесенский [1, 99]; [2, 192, 199]; [4, 139]; [7, 186] (Илл. 1, литера Б), другие допускают, что это мог быть Банковский (Демидов) мост [13, 197] (Илл. 1, литера Г). Вознесенский мост представляется более соответствующим тексту романа, а именно - описанию пути Раскольникова к -му мосту от Сенной площади, и вот почему. С площади герой выходит «коротеньким переулком, делающим колено и ведущим с площади в Садовую» (122). Этому описанию соответствует только один переулок - Таиров (Бринько) (Илл. 1). Выйдя по нему на Садовую, Раскольников двигается далее по улице до «Хрустального 
дворца» (123). Таиров переулок здесь задает направление маршруту героя от площади по Садовой на запад, то есть в сторону Вознесенского проспекта (Илл. 1). Если бы Раскольников двигался в сторону Банковского моста (Илл. 1, литера Г), ему не нужно было бы идти Таировым переулком.

Если допустить, что Раскольников в шестой главе второй части романа стоял на Вознесенском мосту, то возможно следующее предположение относительно того, как, двигаясь от моста в сторону полицейской конторы, он мог оказаться возле дома старухи-процентщицы.

В тексте романа говорится: «...двинулся с моста и направился в ту сторону, где была контора. <...> В контору надо было идти всё прямо и при втором повороте взять влево: она была тут в двух шагах» (132). Данное описание может указывать на так называемый старый съезжий дом Казанской полицейской части, который находился по адресу: набережная Екатерининского канала, 105 (Илл. 1, цифра 8) 21 . Чтобы дойти до этого дома от Вознесенского моста, действительно, нужно миновать два поворота - на Фонарный и Львиный ${ }^{22}$ переулки, а от Львиного «взять влево», так как сама набережная здесь довольно круто поворачивает налево. Возможно, именно поэтому Достоевский говорит не «повернуть налево», а «взять влево», так как полноценного поворота здесь нет. «Но, дойдя до первого поворота, он остановился, подумал, поворотил в переулок и пошел обходом, через две улицы...» (132) - так двигается герой в романе. В соответствии с нашими предположениями, первый поворот - это, действительно, поворот в переулок - Фонарный. «Через две улицы» в данном случае может означать, что Раскольников пошел к съезжему дому Казанской части по Фонарному, думая затем повернуть на Офицерскую улицу и дойти до конторы по ней (Илл. 1). Однако, повинуясь бессознательному импульсу, Раскольников, вместо того, чтобы идти по переулку прямо, мог дойти только до угла Большой Мещанской (Казанской) улицы и повернуть в нее. В этом случае, сделав по ней не более ста шагов, он, действительно, должен был оказаться «у самых ворот» старухиного дома (Илл. 1).

Исходя из этих рассуждений, получается, что Раскольников, решив в первый раз идти в полицейскую контору, чтобы сознаться в убийстве, идет не в свою квартальную полицейскую контору, а в «районное отделение полиции», то есть - в съезжий дом Казанской части, причем описанный в романе маршрут наиболее четко указывает на так называемое «старое здание Казанской части», находившееся по адресу: набережная Екатерининского канала, 105 - и выходившее другой своей стороной на Офицерскую улицу (Декабристов), 30. Однако в 1865 году съезжий дом Казанской части уже имел другой адрес: наб. Екатерининского канала, 101 / Офицерская, $28^{23}$. Разрешить это противоречие можно, предположив, что Достоевский либо не хотел намекать на действующий адрес съезжего дома той полицейской части, в которой он сам в тот момент проживал [12, 68-70], 
либо не придавал большого значения тому, что адрес устаревший. Здесь уместно будет вспомнить слова академика Лихачева о том, что топографическая точность была методом творчества Достоевского, а не его художественной целью $[8,55]$.

Подводя итоги, можно сказать, что предлагаемая нами версия адреса «дома старухи-процентщицы» - Казанская ул., 60 / Фонарный пер., 18 / наб. кан. Грибоедова, 83 - вызывает меньше противоречий с текстом романа, чем наиболее распространенная на данный момент версия, и заслуживает внимания исследователей романа «Преступление и Наказание».

\section{ПРИМЕЧАНИЯ}

Автор выражает благодарность сотрудникам читальных залов БАН и ЦГИА СПб за помощь в работе с источниками информации при подготовке данной статьи.

1 Достоевский Ф. М. Полн. собр. соч.: в 30 т. Т. 6. Л.: Наука, 1973. С. 69-70. Далее ссылки на это издание и том приводятся в тексте статьи с указанием страницы в круглых скобках.

2 Действие романа «Преступление и Наказание», по замыслу автора, происходит в июле 1865 года, см.: [4, 40]; [13, 45-46].

3 Границы Казанской полицейской части см.: Путеводитель по С. Петербургу. Съ приложеніемъ программъ всъхъ учебныхъ заведеній и 6-ти плановъ Петербурга / составилъ и издалъ А. П. Червяковъ. С. Петербургъ.: [Типографія А. П. Червякова], 1865. С. 10-11.

4 По всем рассматриваемым разными исследователями версиям «дом Раскольникова» находится в Столярном пер. [13, 47-48, 201-202], который в июле 1865 года весь относился к 3-му кварталу Казанской полицейской части (см. примечания 2 и 20).

5 Здесь и далее см.: Список переименованных топонимов Петербурга (Приложение) // Анциферов Н. П. Душа Петербурга. Петербург Достоевского. Быль и миф Петербурга / вступ. ст. Д. С. Лихачева; сост. и комм. К. А. Кумпан, А. М. Конечного. М.: Книга, 1991. С. 96-98 (репринт).

6 Границы Юсупова сада в 1865 году см.: План столичного города Санкт-Петербурга, вновь снятый в 1858 году, гравированный при Военно-топографическом депо в 1860. Испр. по 1865-й год. [СПб.], 1865 // Петербургская градостроительная графика XVIII-XXI вв.: планы, схемы, карты, диаграммы, рисунки, статистика / сост. Ю. Киселева, И. Бондаренко, И. Ксенофонтова. СПб., 2012. С. 154-155, 160.

7 Архитекторы-строители Санкт-Петербурга середины XIX - начала XX века: справочник / авт.-сост. А. М. Гинзбург, Б. М. Кириков, при участии С. Г. Федорова, Е. В. Филиппова; под общ. ред. Б. М. Кирикова. СПб.: Пилигрим, 1996. С. 269.

8 ЦГИА СПб. Ф. 513. Оп. 102. Л. 11, 11 об., 19, 19 об., 22, 22 об.

9 Описаніе улицъ С.-Петербурга и фамиліи домовладъльцевъ къ 1863 году / составилъ Н. Цыловъ. Санктпетербургъ: Типографія Товарищества «Общественная Польза», 1862. C. $99,211,424$.

10 ЦГИА СПб. Ф. 513. Оп. 102. № 3321. Л. 11-24.

11 Там же. Л. 1-99.

12 Там же. Л. 22.

13 Там же. Л. 22 об.

14 Там же. Л. 24.

15 Там же. Л. 20-21. 

Собственной Е. И. В. Канцеляріи], 1865. С. 5. и фамиліи домовладъльцевъ къ 1863 году. С. 99; Справочный указатель по С.-Петербургу. С. 5; Всеобщая адресная книга С.-Петербурга, съ Васильевскимъ островомъ, Петербургскою и Выборгскою сторонами и Охтою. Въ 5-ти отдъленіяхъ / [с предисл. Гоппе и Корнфельд]. Изданіе Гоппе и Корнфельда. С. Петербургъ, 1867-68. С. 42.

Там же. Л. 12-13.

Там же. Л. 23-24.

Там же. Л. 12-13, 20-21.

О данной версии адреса «дома Раскольникова» см.: [2, 198-201]; [13, 47, 201-202].

Справочный указатель по С.-Петербургу. С.-Петербургъ: [Въ типографіи II Отдъленія

Расположение съезжих домов Казанской части см.: Описаніе улицъ С.-Петербурга Короткий переулок между Львиным мостом (Илл. 1, литера А) и Офицерской улицей. См. примечания 2, 19 и 20.

\section{СПИСОК ЛИТЕРАТУРЫ}

1. Анциферов, Н. П. Петербург Достоевского / Н. П. Анциферов ; илл. М. В. Добужинского. - Петербург : Брокгауз-Ефрон, 1923 (репринтное воспроизведение, [1991]). - 106 с.

2. Батист, Г. «Дом Раскольникова» [запись беседы с Б. В. Федоренко] / Г. Батист // Белые ночи: о тех, кто прославил город на Неве : очерки, зарисовки, документы, воспоминания / сост. И. И. Слобожан ; ред. колл.: М. К. Аникушин и др. - Ленинград : Лениздат, 1974. - С. $188-204$.

3. Белов, С. В. Петербург Достоевского. Научное издание / С. В. Белов. - Санкт-Петербург : Алетейя, 2002. - 372 с. - (Петербургская серия).

4. Белов, С. В. Роман Ф. М. Достоевского «Преступление и наказание». Комментарий / С. В. Белов ; под ред. Д. С. Лихачева. - Изд. 3-е, испр. и доп. - Москва : КомКнига, 2010. -240 c.

5. Бунатян, Г. Г. Литературные места Петербурга. Путеводитель / Г. Г. Бунатян. - СанктПетербург : Паритет, 2015. - 397, [2] с.

6. Красков, Ю. «Живу в доме Шиля» / Ю. Красков, Б. Метлицкий // Вечерний Ленинград. 1971. — № 267 (7958). - С. 3.

7. Кумпан, К. А. Наблюдения над топографией «Преступления и наказания» / К. А. Кумпан, А. М. Конечный // Известия АН СССР. Серия литературы и языка. - 1976. - Т. 35, № 2. - С. 180-190.

8. Лихачев, Д. С. Достоевский в поисках реального и достоверного / Д. С. Лихачев // Литература - реальность - литература / Д. С. Лихачев. - Ленинград : Советский писатель, 1981. - С. 53-72.

9. Лихачев, Д. С. Там, где жил Достоевский / Д. С. Лихачев, С. В. Белов // Литературная газета. - 1976. - № 30 (4576). - С. 7.

10. Лурье, Л. Я. Петербург Достоевского. Исторический путеводитель / Л. Я. Лурье. Санкт-Петербург : БХВ-Петербург, 2012. - 352 с.

11. Саруханян, Е. П. Достоевский в Петербурге / Е. П. Саруханян. - Ленинград : Лениздат, 1972. $-280 \mathrm{c}$.

12.Тихомиров, Б. Н. Адреса Достоевского в Петербурге : критический анализ источников и экспертиза краеведческих публикаций / Б. Н. Тихомиров // Неизвестный Достоевский : международный научный журнал [Электронный ресурс]. - 2015. - № 1. - 


\title{
C. 38-103. - URL : http://unknown-dostoevsky.ru/files/redaktor_pdf/1438253169.pdf (01.10.2016).
}

13. Тихомиров, Б. Н. «Лазарь! Гряди вон!». Роман Ф. М. Достоевского «Преступление и наказание» в современном прочтении : книга-комментарий / Б. Н. Тихомиров. - СанктПетербург : Серебряный век, 2005. - 472 с.

14. Холшевников, В. Е. Федор Михайлович Достоевский / В. Е. Холшевников // Литературные памятные места Ленинграда : очерки / под общ. ред. А. М. Докусова. - Ленинград : Лениздат, 1959. - С. 399-434.

15. Schmid, U. Dostoevsky and regicide: the hidden topographical meaning of Crime and punishment / U. Schmid // Dostoevsky studies. New series. - 2016. - Vol. 19. - P. 51-62.

\section{Yulia A. Dunaeva}

Junior Researcher

Federal State-Funded Institution of Science

"The Library of the Russian Academy of Sciences"

djdiuna@rambler.ru

\section{ONE MORE VERSION OF THE ADDRESS OF THE “OLD PAWNBROKER'S HOUSE”}

\begin{abstract}
The article indicates to the discrepancy between the most common version of the address of the "Old Pawnbroker's House" - Griboyedov canal, 104 - and the text of the novel "Crime and Punishment". Basing on previous researches of other authors and on her own findings the author argues that a possible location of the "Old Pawnbroker's House" might be somewhere on the right bank of the Griboyedov canal and to the West of Stolyarnyi Alley. The author suggests a new version of the address - Kazanskaya Street, 60 / Fonarny Alley, 18 / Griboyedov Canal Embankment, 83.
\end{abstract}

Keywords: "Crime and Punishment" topography, the "old pawnbroker's house"

\section{REFERENCES}

1. Antsiferov N. P. Peterburg Dostoevskogo [Petersburg of Dostoevsky]. Petersburg, BrokgauzEfron Publ., 1923. 106 p.

2. Batist G. «Dom Raskol'nikova» ["Raskolnikov's House”]. Belye nochi: O tekh, kto proslavil gorod na Neve: ocherki, zarisovki, dokumenty, vospominaniya [White Nights: About those who Glorified the City on the Neva River: Sketches, Drawings, Documents, Memories]. Leningrad, Lenizdat Publ., 1974, pp. 188-204.

3. Belov S. V. Peterburg Dostoevskogo [Petersburg of Dostoevsky]. Saint Petersburg, Aleteyya Publ., 2002. 372 p.

4. Belov S. V. Roman F. M. Dostoevskogo «Prestuplenie i nakazanie». Kommentariy [The Novel "Crime and Punishment" by F. M. Dostoevsky. Comments]. Moscow, KomKniga Publ., 2010. $240 \mathrm{p}$.

5. Bunatyan G. G. Literaturnye mesta Peterburga [Literary Places of Petersburg]. Saint Petersburg, Paritet Publ., 2015. 397 p.

6. Kraskov Yu. "Zhivu v dome Shilya» ["I Live in the House of Shilya”]. Vecherniy Leningrad, 1971, no. 267 (7958), p. 3. 
7. Kumpan K. A. Nablyudeniya nad topografiey «Prestupleniya i nakazaniya» [Observations on the Topography of "Crime and Punishment"]. Izvestiya Akademii Nauk SSSR. Seriya literatury i yazyka [Bulletins of the Academy of Sciences of the USSR. The Series of Literature and Language], 1976, vol. 35, no. 2, pp. 180-190.

8. Likhachev D. S. Dostoevskiy v poiskakh real'nogo i dostovernogo [Dostoevsky in Search of the Real and the Reliable]. Literatura - real'nost' - literatura [Literature - Reality Literature]. Leningrad, Sovetskiy pisatel' Publ., 1981, pp. 53-72.

9. Likhachev D. S. Tam, gde zhil Dostoevskiy [The Place Where Dostoevsky Lived]. Literaturnaya gazeta, 1976, no. 30 (4576), p. 7.

10. Lur'e L. Ya. Peterburg Dostoevskogo. Istoricheskiy putevoditel' [Petersburg of Dostoevsky. Historical Guide]. Saint Petersburg, BHV-Petersburg Publ., 2012. 352 p.

11. Sarukhanyan E. P. Dostoevskiy v Peterburge [Dostoevsky in Petersburg]. Leningrad, Lenizdat Publ., 1972. 280 p.

12. Tikhomirov B. N. Adresa Dostoevskogo v Peterburge: kriticheskiy analiz istochnikov i ekspertiza kraevedcheskikh publikatsiy [Dostoevsky's Addresses in Petersburg: Critical Analysis of Sources and Examination of Regional Publications]. Neizvestnyy Dostoevskiy. Mezhdunarodnyy nauchnyy zhurnal [The Unknown Dostoevsky: International Research Journal], 2015, no. 1, pp. 38-103. Available at: http://unknown-dostoevsky.ru/files/redaktor_pdf/1438253169.pdf (accessed 01 October 2016).

13. Tikhomirov B. N. «Lazar'! gryadi von». Roman F. M. Dostoevskogo «Prestuplenie i nakazanie» $v$ sovremennom prochtenii: Kniga-kommentariy [“Lazarus! Come forth”. Dostoevsky's Novel "Crime and Punishment" in Modern Interpretation: Commentary]. St. Petersburg, Serebryanyy vek Publ., 2005. 472 p.

14. Kholshevnikov V. E. Fedor Mikhaylovich Dostoevskiy [Fyodor Mikhaylovich Dostoevsky]. Literaturnye pamyatnye mesta Leningrada [Literary Memorable Places of Leningrad]. Leningrad, Lenizdat Publ., 1959, pp. 399-434.

15. Schmid U. Dostoevsky and Regicide: the Hidden Topographical Meaning of Crime and Punishment. Dostoevsky Studies. New Series. 2016, vol. 19, pp. 51-62.

Дата поступления в редакиию: 01.11.2016

(C) Ю. А. Дунаева, 2016 